\title{
Regulating internet access in UK public libraries: legal compliance and ethical dilemmas
}

\author{
Adrienne Muir \\ Department of English, Drama and Publishing, Loughborough University, \\ Loughborough, UK \\ Rachel Spacey \\ Vice-Chancellor's Office, University of Lincoln, Lincoln, UK \\ Louise Cooke \\ Centre for Information Management, School of Business and Economics, \\ Loughborough University, Loughborough, UK, and \\ Claire Creaser \\ School of Business and Economics, Loughborough University, \\ Loughborough, UK
}

\begin{abstract}
Purpose - This paper aims to consider selected results from the Arts and Humanities Research Council (AHRC)-funded "Managing Access to the internet in Public Libraries" (MAIPLE) project, from 2012-2014. MAIPLE has explored the ways in which public library services manage use of the internet connections that they provide for the public. This included the how public library services balance their legal obligations and the needs of their communities in a public space and the ethical dilemmas that arise.

Design/methodology/approach - The researchers used a mixed-method approach involving a review of the literature, legal analysis, a questionnaire survey and case studies in five public library authorities.

Findings - UK public library services use a range of methods to regulate internet access. The research also confirms previous findings that filtering software is an ubiquitous tool for controlling access to and protecting library users from "inappropriate", illegal and harmful internet content. There is a general, if sometimes reluctant, acceptance of filtering software as a practical tool by library staff, which seems to contrast with professional codes of ethics and attitudes in other countries. The research indicates that public library internet access will be a valued service for some time to come, but that some aspects of how public library services regulate internet access is currently managed can have socially undesirable consequences, including blocking legitimate sites and preventing users from accessing government services. Education could play a greater part in helping the general population to exercise judgement in

(C) Adrienne Muir, Rachel Spacey, Louise Cooke, Claire Creaser. Published by Emerald Group Publishing Limited. This article is published under the Creative Commons Attribution (CC BY 3.0) licence. Anyone may reproduce, distribute, translate and create derivative works of this article (for both commercial \& non-commercial purposes), subject to full attribution to the original publication and authors. The full terms of this licence may be seen at http://creativecommons.org/ licences/by/3.0/legalcode

This work was supported by the Arts and Humanities Research Council (AHRC) (grant number $\mathrm{AH} / \mathrm{J} 005878 / 1)$.
\end{abstract}

Regulating internet access

Received 18 February 2015 Revised 14 July 2015 Accepted 15 July 2015

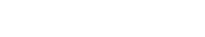


JICES

14,1

88

selection of materials to view and use. This does not preclude implementing stricter controls to protect children, whilst allowing public libraries to continue providing a social good to those who are unable to otherwise participate in the digital age.

Research limitations/implications - The response to the survey was 39 per cent meaning that findings may not apply across the whole of the UK. The findings of this study are compared with and supplemented by other quantitative sources, but a strength of this study is the depth of understanding afforded by the use of case studies.

Originality/value - This paper provides both a quantitative and qualitative analysis of how internet access is managed in UK public libraries, including how library services fulfil their legal obligations and the ethical implications of how they balance their role in facilitating access to information with their perceived role as a safe and trusted environment for all members of their communities. The findings add to the international discussion on this issue and stimulate debate and policy making in the UK.

Keywords Censorship, Public libraries, Freedom of expression, Information ethics, internet access

Paper type Research paper

\section{Introduction}

Managing access to, and use of, internet connections in public libraries raises issues that library authorities must grapple with. These include preventing misuse of internet connections and access to unlawful material by members of the public. Protecting children from exposure to material that may cause them harm, or any public library user from being offended by what others are viewing online, is also a key concern. Public library authorities use a variety of methods to address these issues, including technical measures to control access to content and providing guidance on what is and is not acceptable behaviour. Filtering internet access is a commonly used management tool. However, this imperfect method raises as many issues as it seeks to address. Monitoring user behaviour to identify the misuse of internet connections raises privacy concerns. Blocking access to internet material or services that are lawful, but potentially harmful or offensive to some members of the public, could be considered censorship and contrary to the fundamental purpose of public libraries.

Much of the literature on managing public library internet access originates from the USA. The management of internet access in US public libraries is shaped to some extent by legislation. The constitutionality of the Children's Internet Protection Act (CIPA) and the legality of US public library filtering policies have been subject to legal challenge. The US Supreme Court ruled that CIPA was constitutional because it provides that material deemed unsuitable for children should not be restricted for adults as a matter of course (Sobel, 2003, p. 15). The American Library Association (ALA) and the American Civil Liberties Union (ACLU) have been very vocal in their opposition to filtering (Bertot et al., 2010). The arguments against the use of filtered internet access are principally related to the technical limitations of the software and the ethical implications of restricting access in this way. An example of the limitations of filtering software is a 2011 Australian survey, where 44 per cent of respondents had received complaints of "restricted access because filters blocked valid, legitimate, inoffensive sites in error; limits on file size downloads, and general objections to the ethos of filtering" (Australian Library and Information Association, 2011, p. 23). 
According to Sturges (2002, p. 55):

Regulating

The use of filtering software to block access to internet content is often talked of as if it were internet access merely a technical matter, but in fact it is almost entirely a question of ethics.

Much of the professional debate on this issue focuses on the ethical implications of filtering for members of a profession committed to providing information freely and without bias (Sobel, 2003; Trushina, 2004; Cooke, 2004; Radom, 2007; McMenemy, 2009). The ALA is clear that in spite of the CIPA ruling, it "does not recommend the use in libraries of filtering technology that blocks constitutionally protected information" (American Library Association, 2003, p. 3) and goes on to advise libraries that do use filtering software "to set their filters at the least restrictive level in order to minimize the blocking of Constitutionally protected speech" (American Library Association, 2003, p. 10). The Australian Library and Information Association (ALIA) supported the Australian government's Protecting Australian Families Online initiative for home use (2006), "but does not recommend the use of internet filtering technology in public libraries" (Australian Library and Information Association, 2007, p. 4). Internationally, the IFLA Position on Internet Governance is clear that:

Measures which may be necessary to ensure the reliable operation of the Internet, control spam, support intellectual property protection and enable individuals to protect their privacy must not be used to limit the rights expressed in the Universal Declaration of Human Rights (International Federation of Library Associations and Institutions, 2005).

The potential implications of commercial organizations' involvement in filtering of library internet connections have been explored, including the religious influence on filtering software being used in schools (Willard, 2002) and public libraries (Radom, 2007). Kranich (2004) argues that staff at filtering software companies cannot possibly review all the publicly available websites, yet they are unwilling to disclose the criteria they use for filtering, deeming it commercially sensitive information. Bertot et al. (2010, p. 170) state that:

Some of these commercially available filtering products actually record users' actions online, and have been recently discovered to have created a new income stream by disclosing young people's online searches and chat logs to marketing agencies.

Education and training by library staff has been suggested as a means of helping library users navigate the internet safely and lawfully (Kranich, 2004; Heins et al., 2006; Byron, 2008; International Federation of Library Associations and Institutions, 2009). McMenemy and Burton (2005, p. 21) recommend that Acceptable Use Policies (AUPs) are "backed up with a robust internet skills approach to ensure customers know just what the internet does and what is out there for them and their children". However, Colaric $(2003$, p. 9) questions the role education could play in safe internet use by children. Schacter et al. (1998, cited in Colaric, 2003) found that children tend to assume that what they find on the internet is accurate. Pors (2001) suggests that library assistants are more inclined to favour filtering than librarians because assistants have more first-hand experience of problems related to internet access. It has also been argued that filtering software offers a greater degree of control to the end user thereby supposedly balancing the right to freedom of expression with the right not to encounter offensive content (Burt, 1997; Auld, 2003). This raises the question of whether there is a universal right not to be offended. 
JICES

14,1

90

Misuse of internet access is not limited to accessing pornography. Pors's (2001, p. 310) study of internet use in public libraries in Denmark found that 33 per cent of public library services had registered some kind of misuse incident or suspicion of an incident:

It is evident from the answers that the librarians see misuse not only as phenomena like the downloading of pornographic, racist and Nazist material, but also changing the configuration of the computers, installation of start-up pictures of a dubious kind and different types of noise problems.

Acceptable use policies (AUPs) describes prohibited activities, such as viewing pornography or infringing copyright, and "tend to be used by organizations to pass some element of liability onto the customer when accessing Internet services" (McMenemy and Burton, 2005, p. 21). Displaying an AUP prominently in the library is recommended as a useful deterrent (Minow, 2004, p. 11), but library users may not pay attention to, or fully understand, AUPs (Comer, 2005; Poulter et al., 2009). However, research with staff in Singapore's public libraries suggests AUPs give staff confidence in managing internet use (Heok and Luyt, 2010, p. 483). Kranich (2004, p. 16) states that:

The vast majority of citizens use the internet and other library materials responsibly, guided by the local library internet access policies and codes of conduct that address appropriate use and invoke disciplinary action if rules are violated.

As early as 1997, an academic librarian considered the tensions inherent when there are "competing interests of computer users who wish to access sexually-explicit materials and those who find them offensive" (Young, 1997, p. 49). Still and Kassabian (1999, p. 20), also writing about academic libraries, suggested positioning of furniture to ensure personal computers (PCs) are on public view to "hinder inappropriate use of library terminals". Conversely, Gottschalk (2006) states:

Many libraries have found that recessed monitors and well displayed Internet use policies, explaining acceptable and unacceptable Internet behaviour enable patrons to understand and take responsibility for online research and entertainment in public places.

As well as visually monitoring internet use, public library services may collect usage data (Australian Library and Information Association, 2011). Staff may also have the technology to view user screens remotely (Poulter et al., 2009).

\section{Internet access in UK public libraries}

British public library authorities have a statutory duty "to provide a comprehensive and efficient library service for all persons desiring to make use thereof" (Public Libraries and Museums Act, 1964, s. 7[1]). No public library can provide a fully comprehensive service, but must meet the needs of the local community as far as possible with increasingly limited resources. In the UK, the Society of Chief Librarians (SCL, 2014) recognises that the aim must be to keep library services "relevant and accessible". To this end, the SCL (2014), along with partners, has developed the concept of the Universal Offer, which is a vision for a modern public library service that meets the expectations of the public. It recognizes the importance of facilitating access to digital services, including providing internet access.

The People's Network (Department for Culture Media and Sport, 1998; Library and Information Commission, 1997, 1998) was an initiative to further a number of policy 
goals including lifelong learning, digital citizenship and reducing social exclusion. Library internet services would support citizens without connections at home or work and help them develop digital literacy skills The focus was on installing network infrastructure and skills development More recently, the UK Government announced that $£ 74$ million funding was to be made available "to give wi-fi access to all public libraries across England” (Farrington, 2015, n.p.). By providing internet access, public libraries potentially increase their ability to fulfil their statutory obligation to provide a "comprehensive" service. However, UK public library authorities regulate access in various ways. They manage demand by imposing time limits on access and, in some cases, imposing charges. They also use AUPs and filtering software.

The aim of the MAIPLE research project was to address a knowledge gap by identifying and quantifying measures implemented in UK public libraries to regulate and manage access to internet content and services. One aspect of the research was identifying and analysing legal and ethical issues, that is, how public libraries strive to meet their legal obligations and the compromises they make to serve diverse user communities. This included the dilemmas emerging from the need to balance supporting access to information for all with ethical and moral pressures exerted by politicians, parents and interest groups. The aim of this paper is to report and discuss the findings from the legal and ethical strand of the MAIPLE project. It describes the legal and ethical frameworks within which public libraries provide services. It presents relevant findings from the research project and an analysis of how public library authorities respond to legal obligations and moral pressures. The implications of the decisions made by library authorities are considered within the context of human rights frameworks and professional ethical codes. Finally, recommendations are offered, focusing on how public libraries can best achieve an equitable balance between their legal obligations and ethical imperatives within a challenging political, financial and moral attitude climate.

\section{Research methods}

The Arts and Humanities Research Council-funded MAIPLE project ran from September 2012 to August 2014. The project Advisory Board supported and guided the project team. The first stage of the project was a comprehensive review of the literature, starting with the publication of New Library: The People's Network (Library and Information Commission, 1997), as this document played a seminal role in the implementation of internet access across the UK public library sector. The review was international in scope and included: academic and professional journal articles; monographs; research reports and reviews; theses; newspaper articles; guidance and policy documents; and legal instruments The full review is published elsewhere (Spacey et al., 2014), and only selected relevant literature is discussed in this paper.

The main primary data gathering activities were a questionnaire survey of all UK public library authorities and in-depth case studies of five authorities. The findings are reported in Spacey et al. (2013). The surveys were sent to all 206 public library authorities. A total of 80 responses were returned, a response rate of 39 per cent. The case studies were drawn fromall the constituent parts of the UK, including the unitary authority covering the whole of Northern Ireland. The aim of the survey was to gather baseline data on how public libraries manage internet access and the problems they have encountered in practice. The aim of the case studies was to explore the issues in more depth and involved analysis of policy and 
JICES

14,1

92

other documents and a series of interviews with library staff and users. The case study discussions included staff and user views on the ethical aspects of managing access to internet content and user behaviour online.

\section{Findings}

The legal framework relevant to public library internet access provision

As a signatory to the European Convention on Human Rights (1950) (ECHR), the UK must uphold the rights embodied in the Convention's articles. Public authorities should not arbitrarily interfere with the fundamental rights of citizens. The right to freedom of expression includes imparting and receiving information and ideas [Article 10(1)]. This right is not absolute, and public authorities may impose restrictions for certain specified purposes, primarily relating to national security, the public good and upholding other rights. Such curbs should be "prescribed by law and necessary in a democratic society" [Article 10(2)]. Individuals have the right to freedom of thought, conscience and religion (Article 9). Again, this is a qualified right and is subject to lawful limitations [Article 9(2)]. Article 8(1) of the ECHR states that "Everyone has the right to respect for his private and family life, his home and his correspondence”. Public library authorities should only interfere with these rights in similar circumstances to those which apply to the right to freedom of expression [Article 8(2)].

The UK also has obligations under the United Nations Convention on the Rights of the Child (1989). This Convention focuses on safeguarding people under the age of 18 and helping them to flourish. Some rights are analogous to those of the ECHR, for example, freedom of expression and respect for privacy (Article 13 and 16). Other rights that are relevant to public library services are the positive right to education (Article 28) and various other rights amounting to a right to be safe from harm. The UK has given effect to the Convention through several pieces of legislation, including the Children Acts of 1989 and 2004, the Children (Scotland) Act 1995 and the Children (Northern Ireland) Order 1995. A key provision, common to these statutes and relevant to public library authorities, is for cooperation by public agencies to protect children.

UK public libraries are subject to other obligations in domestic law. These include the Data Protection Act, 1998. Public libraries are data controllers as far as registered members are concerned and may also collect some personal data from casual users who wish to access library internet connections. Processing personal data is subject to the eight principles described in Schedule 1 of the Act. These principles are designed to ensure responsible data handling.

Public libraries should not infringe copyright or facilitate copyright infringement by their users. Public libraries are able to lend books under an exception to UK copyright law (Copyright, Designs and Patents Act, 1988, s. 40A), with payments made to authors by the government under the Public Lending Right Act, 1979 (s. 1). The Digital Economy Act, 2010 includes provisions for online copyright enforcement and requires rights holders to work with internet service providers (ISPs) to identify alleged copyright infringement, identify the perpetrators and to contact them to inform them of the consequences of continuing to infringe (Digital Economy Act, 2010, s. 3). There was some concern in the library community about the status of libraries under this law and whether they could become liable for infringement by their users. At the time of writing, it seems unlikely that these provisions of the Digital Economy Act, 2010 will ever come into force; in practice, their aims are being implemented through other means. These 
include using existing provisions in copyright law to obtain court orders to block access to infringing sites (Copyright Designs and Patents Act, 1998, s. 97A). Rights holders and ISPs are cooperating voluntarily on a programme (Department for Business, Innovation and Skills, 2014) to alert and educate users about alleged copyright infringements (Voluntary Copyright Alert Programme, now called Creative Content UK).

Although public libraries may not be held liable for unlawful activity by people using library internet connections, they may have an obligation to report unlawful behaviour if they become aware of it. For example, this would be the case if users commit offences under laws on obscene publications and child pornography (Obscene Publications Act, 1959, s. 2 and Protection of Children Act, 1978, s. 160) or various communication laws (for example, under Section 127 of the Communications Act, 2003, the Malicious Communications Act, 1998 and the Telecommunications Act 1984).

\section{The ethical framework for UK public librarians}

Employees of public library authorities are subject to corporate policies and the professional codes of conduct of any professional associations they belong to. In the UK, the Chartered Institute of Library and Information Professionals (CILIP) has developed ethical principles and a code of professional conduct, which set out underpinning values and guidance for members. Some of the principles embody legal responsibilities, including human rights and equality. There is a commitment to defending access to information and reference to balancing the needs of users with employer demand, which is relevant to corporate policies on filtering internet access. The CILIP (2012) code of practice shows an awareness of the need to balance the interests of users with legal obligations and to deal fairly with conflicting user needs. For example, practitioners must:

- protect the confidentiality of all matters relating to information users, including their enquiries, any services to be provided and any aspects of the users' personal circumstances or business;

- deal fairly with the competing needs of information users and resolve conflicting priorities with due regard for the urgency and importance of the matters being considered;

- defend the legitimate needs and interests of information users while upholding the moral and legal rights of the creators and distributors of intellectual property;

- consider the public good, both in general and as it refers to particular vulnerable groups, and the immediate claims arising from their employment and their professional duties; and

- promote equitable access for all members of society to public domain information of all kinds and in all formats.

Another point in the code becomes relevant when considering the extent to which public libraries try to protect their users from "inappropriate" material on the internet:

- promote the necessary skills and knowledge amongst users to become effective independent learners and researchers.

CILIP "does not endorse the use of filtering especially for adult users" (CILIP, 2011, pp. 12-13). At the same time, CILIP acknowledges the need to discourage users from viewing illegal sites, "associated with child pornography, race hate or terrorism" or 
JICES

14,1

using computers and internet connections "for other types of unlawful or undesirable behaviour - notably hacking, spreading viruses or as an aid to criminal activity” (p. 12). The ALA (2003, p. 3) and ALIA (2007, p. 4) also do not support filtering that blocks access to legitimate information.

The IFLA code of ethics for librarians and other information workers (2005) covers similar ground to the CILIP code and requires that "Librarians and other information workers respect the protection of minors while ensuring this does not impact on the information rights of adults" (s. 2) (International Federation of Library Associations and Institutions, 2014). The Standing Committees of the IFLA Libraries for Children and Young Adults Section and the Reading Section accepted a statement relating to the internet and children's library services at the annual World Library and Information Congress in 2007 (International Federation of Library Associations and Institutions, 2012). They argued that filtering and censorship do not work and advocated effective education of children, parents, teachers and libraries.

\section{Regulating the use of the internet in public libraries: the issues}

The Library and Information Commission (LIC, 1998) was the crucial advocate for introducing internet access in UK public libraries. The UK Government funded the "People's Network", an initiative to connect all static public library points to the internet by 2002. CIPFA (2013) reported that 206 library services across the UK were providing fixed access to the internet and wi-fi access was available in 1,553 service points across 160 different authorities (84.2 per cent of those providing information). The MAIPLE project survey received 80 responses, and 83.8 per cent of the respondents offer wi-fi and fixed access to the internet in one or more of their libraries.

Internet access in public libraries is comprehensive in the UK, but it is not free in all senses of the word. All survey respondents require identification of internet users. Almost 88 per cent of respondents require registered library members to input their borrower and PIN numbers. For unregistered users, half of the respondents require proof of identity, whilst a PIN or password is required by almost half of the respondents (47.1 per cent). Only one respondent did not require identification as a condition of use. Identification allows library services to discover who is responsible for any misuse of internet connections. However, it also means that internet use is never entirely private. This raises the question of what reasonable expectations of privacy in a public library should be and the extent to which privacy is respected in public libraries.

Internet access is usually provided without charge for registered library members, and 62 per cent of survey respondents provide free access for anyone. Other approaches include charging visitors for access or a hybrid system where an initial period of use is free and further use is charged for. The Public Libraries and Museums Act 1964 (s. 8) provides that, in general, no charge should be made for straightforward reference use and lending of written material. However, the legislation allows for exceptions to this general rule. Public library authorities can charge for internet access without breaching their statutory duty, but even nominal charges could exclude people in greatest need of public access to online information and public services.

Almost all (98.8 per cent) survey respondents have an AUP. In all, 80 per cent of respondents display this on login screens. Senior library management is most likely to develop policies, although survey respondents also indicated some involvement of 
information technology (IT) staff and legal experts. It seems appropriate that library management takes the lead, as they will be most in touch with library user needs.

All of the survey respondents filter internet access on library PCs. The majority of respondents (83.6 per cent) offering wi-fi access confirmed that this is also filtered. Some categories of material are blocked for all library users by filtering systems: sexual, hacking, violent, intolerant/hate and extremist. Some material in each of these categories will be unlawful in the UK, but not all. This means that public libraries may, in effect, be censoring freely available lawful material. The response rate to the survey was 39 per cent of all public library authorities. Some non-responding authorities may not implement filtering, but if filtering is implemented uniformly across authorities, this raises questions about the fundamental role of public libraries in the digital age.

In all, 89 per cent of survey respondents said that they make users aware that internet access is filtered. Filtering levels for children are usually higher than for adults, and there may be filtering levels specifically for teenagers. The most restrictive approach is the "walled garden". This means that children may only access material selected by library staff. Two survey respondents indicated that they provided this level of access on dedicated children's PCs. The focus of filtering for young people was to encourage learning, but, at the same time, to protect them from unlawful or harmful material. Examples of blocked material and services are gambling; social networking and chat rooms; dating and personals; weapons; illegal drugs; and bad language. Most survey respondents (83.5 per cent) said that they undertake visual monitoring of user activity. However, they indicated that they practised "vigilance" rather than active monitoring. Positioning of PCs is also used as a means of enforcing AUPs. This includes positioning children-only PCs away from those used by adults.

The general attitude of survey respondents towards filtering is that it is useful. Most said that they have infrequent incidents of misuse of internet connections. However, it is not clear what, if any, connection there is between levels of misbehaviour and filtering. Two thirds of respondents have received complaints from the public about filtering and its widespread use is in contrast to the views of library professional associations, such as CILIP (2011). The legal and ethical issues arising from provision of internet access in public libraries were explored in more depth in the five library authority case studies.

In the UK, the issue of new media forms and child protection periodically becomes prominent and the government acts in some way. For example, the former Labour Government ordered an independent review of children's use of the internet and video games and the potentially harmful (especially sexual) content that they may encounter (Byron, 2008). The review recommendations focused on parental responsibility and video game classification. The UK Council for Child Internet Safety was launched in 2008 to work with the internet industry to remove harmful internet content. Encouraging subscribers to use parental controls was the focus of an ISP code of practice (Code of Practice on Parental Controls, 2011). More recently, the current government has focused on default filtering of internet access forcing all new subscribers, whether they have children or not, to opt-out of filtering.

It seems from the survey and interviews that the filtering software is not fully effective, resulting in some undesirable material remaining available and some legitimate material being blocked. This finding is similar to that of earlier research (for example Willson and Oulton, 2000). The problem of over-blocking was also found in 
JICES

14,1

96

later studies (for example, Comer, 2005; Heins et al., 2006; Australian Library and Information Association, 2007; Reading Agency, 2011).

The MAIPLE survey respondents were asked if library users had made any complaints about the filtering software in the past 12 months. Almost two-thirds of respondents (65.8 per cent) stated that they had received complaints, 30.4 per cent had not and 3.8 per cent did not know. Of those services that had received complaints (52), over-blocking was the most frequent cause (88.5 per cent). Over half of respondents ( 53.8 per cent) received complaints about technical limitations on access, such as the inability to upload or share files. Less numerous were complaints about the use of filtering software per se (19.2 per cent). "Other" complaints include users being unable to access online greetings cards, a drug-related website and access to virtual learning environments. Finding that legitimate internet sites are blocked is inconvenient for library users. In some cases, it may interfere with their ability to study or work. For example, one user interviewed for the research project is a freelance photographer and author. The user's research was hampered when the filtering software blocked access to a field sports site they wished to view.

The impact of over-blocking can be lessened if there is a clear, simple and rapid procedure for sites to be unblocked. Findings from the research project survey and interviews indicate that this is not always the case. Fewer than 10 per cent of surveyed library services give front-line library staff the responsibility to respond to filtering requests. Although this option would be the most convenient for users, front-line staff may not feel willing or able to deal with such a request. This may be the case if it is a question of whether or not the blocked material is lawful or if the staff member finds the material offensive. Responsibility for responding to requests to change the filter belongs to library service senior management in over half of responding services (52.5 per cent), by IT staff at local authority level (41.3 per cent) and library service level in approximately two-fifths of services (41.3 per cent). Fifty-three respondents selected only one option (66.3 per cent), whilst 27 respondents (33.8 per cent) selected more than one option. In all, 14 respondents selected two options (17.5 per cent) and 10 respondents selected three options (12.5 per cent). Arguably, it is desirable that more straightforward decisions are taken by library staff, at the appropriate level of seniority and with appropriate skills. It is not clear why local authority IT staff should be involved in decision-making rather than implementing decisions made by library staff. In one service, the IT service is outsourced and filtering responsibility rests with the service provider. This is a minority response, but if it were to become more common, it would raise issues of public services being regulated by commercial entities.

The research project survey respondents indicated that the most commonly used additional measure to regulate internet use is visual monitoring of screens by library staff (83.5 per cent). The positioning of $\mathrm{PC}$ s and use of a booking system are also popular mechanisms (70.9 per cent). Given the increasing provision of wi-fi connections in public libraries, the positioning of work tables and seating would also have to be carefully designed because people can now use their own devices anywhere in the library.

Collecting internet use data is utilized by over two-fifths of the research project survey respondents (44.3 per cent), whilst monitoring software is used in almost a third of responding services (30.4 per cent). "Other" additional measures include staff being vigilant, rather than systematic visual monitoring of internet activity (in three services): "Staff will take action if they happen to see something but do not monitor usage". 
Practical measures such as internet safety posters are used in one service, whilst another runs a volunteer-led "computer buddies" programme. Two services use technological measures such as adjusting the filtering categories, whilst in one service, monitoring internet access software is about to be introduced.

Library staff and users' views on regulating internet access

Staff members interviewed for the case studies indicated that they were aware of few serious instances of internet misuse. A theme that emerged strongly in the interviews is a perceived need to provide a "safe" environment for all library users. Staff accepted the need to protect children from harm and interviewees often used the terms "safety" and "risk". Interviewees mentioned pressure from parents and teachers. Some interviewees indicated that filtering was implemented at a corporate level, meaning that the same level of filtering used in schools was also applied in the public library. Although this was not always the case, stronger filtering for children is the norm in public libraries. It is not clear whether filtering is accompanied by educating children in how to safely use the internet either by parents or in schools.

Library staff perceived filtering as a practical solution to a problem and recognized the need to maintain a balance between providing access and not causing offence when computer screens are publicly visible to others. Library staff must decide whether to intervene when they receive complaints given the subjective nature of offence. The research indicated that staff members adopt a reasonable and fair approach to assessing what is and what is not acceptable. Some decisions are difficult and staff members are sometimes offended by things they have to deal with. Not all interviewees agreed with filtering for adults, but the library as a public space and the public's trust in the library service was emphasized. Sometimes, this view was expressed along the lines of people can do whatever they want in private, but there must be some limits in a public place. Another, less prominent but interesting, view was that some people need to be protected from themselves, for example, in the case of gambling or pay-day loans sites. However, in blocking access to this material, public library authorities are effectively taking on the role of moral guardians.

When asked whether it is ethical to filter internet content in public libraries, 22 staff interviewed felt that it is, whilst 9 expressed some hesitation or regret. For some staff, filtering is a pragmatic means to the end of providing a service to a diverse range of people:

I think inevitably when you are dealing with a whole community; you have to start thinking about if somebody was looking at a site which would be very offensive to another member of the community [...] Total freedom on the Internet I think is a wonderful idea, like total freedom everywhere but if society is going to work I think there's bound to be, there has to be some restrictions (CS2 Library Advisor 1).

Safeguarding children was cited as the justification for filtering, but censoring access to adults seemed to be accepted with, at most, mild regret. Some staff recognized that as a profession, filtering presented a dilemma. For example:

We've a double standard because we say we're fiercely proud of the fact that we don't censor, that we don't censor the published word unless it is something that we're not permitted to carry but we will censor the visual and it's the visual which is the problem (CS4 Operational Manager). 
JICES

14,1

98

The perception of the printed word being somehow less powerful than other forms of expression is reflected in the licensing and rating systems applied to broadcasting, films and computer games.

Users were almost evenly divided between those who were aware the library filtered internet content $(n=13)$ and those who were not $(n=12)$. Two users did not give an answer. Some users explained how they had become aware of filtering: this was because they had experienced site blocking $(n=3)$, because they had noticed it was mentioned in the service's Acceptable Use Policy/Terms and Conditions $(n=3)$ or they had assumed it would be $(n=2)$. There was also some support for filtering amongst the library users. Nineteen users were pro-filtering and eight were unsure. Two users were definite "no's". Users supporting filtering tended to agree that it was appropriate for a number of reasons, including the presence of children, for libraries to maintain standards of public decency and to ensure libraries only provide access to lawful content.

Some library users described instances when access to websites was blocked. These examples included legitimate dating services, field sports and military music sites. Sometimes it was not obvious to either the user or library staff why a site was blocked:

I was looking up something [...] something just anonymous like but it just come up "this site is blocked" and I asked the girl at the desk and she said she didn't know why because it was innocent (CS4 User 3).

The impact of over-blocking on access to information may be compounded by users not feeling able to ask for a site to be unblocked. Of the 21 users that responded to the question of whether they would feel comfortable approaching staff, 11 said that they would feel comfortable, whilst 10 said they would not. Feelings of discomfort tended to focus on how asking staff might make the user feel or how staff might perceive them: "shady"; "embarrassing"; "concerned"; "awkward". In addition, two users in one case study site felt that staff would be unable to help them even if they did ask. Staff members in the five case study services confirmed that they are able to request that sites are unblocked. However, in four of these services, this involves liaison with IT colleagues. This makes the process more time-consuming and also raises the question of whether IT staff are being asked to make qualitative judgements of what should or should not remain blocked rather than information specialists.

Library staff members are aware of the privacy issues raised by internet provision in public libraries. There was little evidence of intrusive monitoring of internet activity, and it seems that library staff members are often alerted to suspected or offensive activities by other users. Some staff thought that monitoring PC screens through the building is a useful, if sometimes limited, way to ensure acceptable use. This method could help staff identify situations where users' privacy might be infringed, for example, by groups of people congregating around computers. A small number of staff was dismissive of visual monitoring because they did not have the time to do it. Monitoring software was also referred to as a useful tool in one case study where the majority of PCs were located in rooms not visible to staff on the front desk, but it was only used if staff were given good reason to do so.

\section{Discussion and conclusions}

The key legal issues for UK public libraries in providing internet access appear to be safeguarding children and ensuring library users do not use library connections to 
undertake other unlawful activities or offend other users. This reflects other findings in the literature. Ethical dilemmas arise from how public library authorities attempt to address these issues. The perception that the public library should be a safe and "decent" place for everyone can mean restricting adult access to lawful material that is deemed unsuitable. The MAIPLE project has confirmed previous findings that filtering software is an apparently ubiquitous tool. The general acceptance of filtering software appears to have been led at a corporate level rather than by library managers (in 48.8 per cent of responding authorities, compared with 30 per cent of authorities in which the decision was led by library managers). This acquiescence appears to contrast with the position in the USA, where there has been strong professional protest at the implementation of filtering (Bertot et al., 2010).

When it comes to material deemed "inappropriate" rather than unlawful, this can be a very subjective judgement. For formally published material, professional publishers have acted as arbiters of quality or taste and librarians have decided what to include in library collections. When it comes to the internet, it appears that filtering software vendors have a prominent role. Library staff indicated that the problem of over-blocking has reduced over time, but it remains a problem for some users. The research provided several examples of users who had unsuccessfully tried to access lawful sites. Moreover, many users felt uncomfortable about asking staff to unblock sites and some would not do so. Despite this, there seems to be a general acceptance of the need for filtering amongst users and library staff. The concept of the library as a safe public space that is to be trusted as the purveyor of reliable, high-quality information (Crook, 1999) appears to outweigh an ethic of "access to all publicly available information" (CILIP, 2005). This raises the question of the fundamental purpose and mission of a public library serviceis it to educate, to inform, to offer recreation and a social space or to improve lives?

The project results suggested that despite the Society of Chief Librarians's vision of the Universal Offer, little attention was paid to user education on appropriate and safe use of the internet. This certainly seemed to be the case in the case study library services. There is a question of who should be responsible for education of younger users. It was suggested that parents and schools should play a greater role, rather than relying heavily on filtering as a solution. The potential for user and staff education, supported by an AUP, seems to have been given a much lower priority than the implementation of filtering software. Moreover, education of users about procedures for unblocking sites also seems to be somewhat ad hoc, leaving some users unable to access legitimate information and unable or unsure how to rectify the situation.

Recording what registered library members borrow from the library has always been possible. However, when it comes to internet access, the amount of data that can be collected about what people do online can be much more intrusive. Real-time surveillance is mostly limited to visual monitoring of screens, but the almost ubiquitous use of automated booking systems and user identification ensures that there is the option of checking online activity histories. This enables staff to identify individuals who breach the AUP, but it may also result in self-censorship on the part of users. Visual monitoring of screens by staff was identified as potentially posing privacy issues, for example, in the case of banking. Fewer privacy concerns appeared to be raised with regard to the arguably more intrusive measure of analysing logs of sites visited. There is also the issue of users being able to see what other users are doing and complaining if 
JICES

14,1

what they feel offended by what they see. There is scope for further research into the privacy implications of monitoring of user activity online in public libraries.

The trend towards filtering internet connections represents a challenge to the right to freedom of expression. As is happening elsewhere in the world, the UK library profession should be engaging more actively in debate on this issue, as it conflicts with its core professional values. The CILIP (2014a) ethical principles include "Commitment to the defence, and the advancement, of access to information, ideas and works of the imagination". This engagement should also extend to the general public, as it seems that child protection and anti-pornography agendas are dominating public awareness and debate. The potential for longer-term erosion of human rights, such as freedom of expression and privacy, do not seem to be fully appreciated by ordinary citizens. The research highlighted the potential for the blunt instrument that technology currently offers further disadvantaging people unable to access public services in any other way. It is perhaps time to understand that strict control of access to material deemed to be inappropriate in some way is neither really possible nor socially desirable. Internet literacy education should play a greater part in helping the general population to exercise judgement in the discovery and selection of materials to view and use. This does not preclude implementing stricter controls to protect children while allowing public libraries to continue providing a social good to those who are unable to otherwise participate in the digital age.

\section{References}

American Library Association (2003), "Libraries and the internet toolkit: tips and guidance for managing and communicating about the internet", available at: www.ala.org/offices/sites/ ala.org.offices/files/content/oif/iftoolkits/litoolkit/2003internettoolkit.pdf (accessed 10 February 2015).

Auld, H. (2003), "Filters work: get over it”, American Libraries, February, pp. 38-42.

Australian Library and Information Association (2007), "Internet filtering in public libraries 2007 survey report", available at: www.alia.org.au/advocacy/internet.access/internet.filtering. public.libraries.2007.survey.report.pdf (accessed 10 February 2015).

Australian Library and Information Association (2011), "ALIA internet access in public libraries survey 2011", available at: www.alia.org.au/advocacy/internet.access/Internet.Access. Survey.2011.pdf (accessed 10 February 2015).

Bertot, J.C., Jaeger, P.T. and McClure, C.R. (Eds) (2010), Public Libraries and the Internet: Roles, Perspectives and Implications, Libraries Unlimited, Santa Barbara, CA.

Burt, D. (1997), “In defense of filtering”, American Libraries, Vol. 28 No. 7, pp. 46-47.

Byron, T. (2008), "Safer children in a digital world, the report of the Byron Review", available at: http://media.education.gov.uk/assets/files/pdf/s/safer \%20children $\% 20$ in $\% 20 \mathrm{a} \%$ 20digital $\% 20$ world \% 20the \%202008\%20byron \%20review.pdf (accessed 10 February 2015).

Chartered Institute of Library and Information Professionals (CILIP) (2005), "Statement on intellectual freedom, access to information and censorship”, available at: www.cilip.org.uk/ sites/default/files/documents/2005_foistatement0705.pdf (accessed 10 February 2015).

Chartered Institute of Library and Information Professionals (CILIP) (2011), "User privacy in libraries: guidelines for the reflective practitioner", available at: www.cilip.org. $\mathrm{uk} /$ cilip/archived-policy-statements/user-privacy-libraries-guidelines-reflectivepractitioner (accessed 10 February 2015). 
Chartered Institute of Library and Information Professionals (CILIP) (2012), "Code of professional practice”, available at: www.cilip.org.uk/cilip/about/ethics/code-professional-practice (accessed 10 February 2015).

Chartered Institute of Library and Information Professionals (CILIP) (2014), "Ethical principles", available at: www.cilip.org.uk/cilip/about/ethics/ethical-principles (accessed 10 February 2015).

Chartered Institute of Public Finance and Accountancy (CIPFA) (2013), "Public library statistics: 2013-2014 estimates and 2012-2013 actuals", available at: www.cipfa.org/policy-andguidance/publications/p/public-library-statistics-201314-estimates-and-201213-actualspdf (accessed 10 February 2015).

Children Act 1989.

Children Act 2004.

Children (Northern Ireland) Order 1995.

Children (Scotland) Act 1995.

Children's Internet Protection Act Title XVII.

Code of Practice on Parental Controls (2011), "Code of practice on parental controls", available at: www.gov.uk/government/uploads/system/uploads/attachment_data/file/251454/code_ of_practice.pdf (accessed 10 February 2015).

Colaric, S. (2003), "Children, public libraries, and the internet: is it censorship or good service?", North Carolina Libraries, Vol. 61 No. 1, pp. 6-12.

Comer, A.D. (2005), "Studying Indiana public libraries' usage of internet filters", Computers in Libraries, Vol. 25 No. 6, pp. 10-15.

Communications Act 2003.

Cooke, L. (2004), "Regulating the internet: policy and practice with reference to the control of internet access and content”, $\mathrm{PhD}$ thesis, Loughborough University, Loughborough.

Copyright, Designs and Patents Act 1998.

Crook, E. (1999), "Public libraries and political ideologies", Australasian Public Libraries and Information, Vol. 12 No. 4, pp. 178-182.

Data Protection Act 1998.

Department for Business, Innovation and Skills (2014), "New education programme launched to combat online piracy", available at: www.gov.uk/government/news/new-educationprogramme-launched-to-combat-online-piracy (accessed 16 April 2015).

Department for Culture Media and Sport (1998), New Library: The People's Network The Government's Response, DCMS, London.

Digital Economy Act 2010.

ECHR (European Convention on Human Rights) (1950), "Convention for the protection of human rights and fundamental freedoms", available at: http://conventions.coe.int/treaty/en/ treaties/html/005.htm (accessed 10 February 2015).

Farrington, J. (2015), “All libraries in England to get wi-fi funding”, The Bookseller, available at: www.thebookseller.com/news/all-libraries-england-get-wi-fi-funding (accessed 9 February 2016).

Gottschalk, L. (2006), "Internet filters in public libraries: do they belong?”, Library Student Journal, available at: www.oalib.com/paper/2200719\#.VNooeMtybDA (accessed 10 February 2015). 
JICES

14,1

Heins, M., Cho, C. and Feldman, A. (2006), Internet Filters: A Public Policy Report, 2nd ed., Brennan Center for Justice at NYU School of Law, New York, NY.

Heok, A.K.H. and Luyt, B. (2010), "Imagining the Internet: learning and access to information in Singapore's public libraries”, Journal of Documentation, Vol. 66 No. 4, pp. 475-490.

International Federation of Library Associations and Institutions (2005), "IFLA position on internet governance”, available at: www.ifla.org/publications/ifla-position-on-internetgovernance (accessed 15 April 2015).

International Federation of Library Associations and Institutions (2009), "Internet and children's library services", available at: www.ifla.org/en/publications/internet-and-children-slibrary-services (accessed 9 February 2015).

International Federation of Library Associations and Institutions (2012), "Internet and children's library services”, available at: www.ifla.org/en/publications/Internet-and-children-slibrary-services (accessed 15 April 2015).

International Federation of Library Associations and Institutions (2014), "IFLA code of ethics for librarians and other information workers", available at: www.ifla.org/news/ifla-code-ofethics-for-librarians-and-other-information-workers-full-version (accessed 10 February 2015).

Kranich, N. (2004), "Why filters won't protect children or adults”, Library Administration and Management, Vol. 18 No. 1, pp. 14-18.

Library and Information Commission (1997), New Library: The People's Network, DCMS, London.

Library and Information Commission (1998), Building the New Library Network, DCMS, London.

McMenemy, D. (2009), The Public Library, Facet Publishing, London.

McMenemy, D. and Burton, P.F. (2005), "Managing access: legal and policy issues of ICT use", in McMenemy, D. and Poulter, A. (Eds), Delivering Digital Services: A Handbook for Public Libraries and Learning Centres, Facet Publishing, London, pp. 19-34.

Malicious Communications Act 1988.

Minow, M. (2004), "Lawfully surfing the net: disabling public library internet filters to avoid more lawsuits in the United States", First Monday, Vol. 9 No. 4, available at: http://firstmonday. org/htbin/cgiwrap/bin/ojs/index.php/fm/article/view/1132/1052 (accessed 15 April 2015).

Obscene Publications Act 1959.

Pors, N.O. (2001), "Misbehaviour in the public library: internet use, filters and difficult people", New Library World, Vol. 102 No. 9, pp. 309-313.

Poulter, A., Ferguson, I., McMenemy, D. and Glassey, R.J. (2009), "Question: where would you go to escape detection if you wanted to do something illegal on the Internet? Hint: shush!", in Jahankhani, H., Hessami, A.G. and Hsu, F. (Eds), 5th International Conference, ICGS3 2009 on Global Security, Safety and Sustainability, Springer-Verlag, New York, NY, pp. 1-8.

Public Lending Right Act (1979).

Protection of Children Act (1978).

Public Libraries and Museums Act (1964).

Radom, R. (2007), "Internet filtering companies with religious affiliations in the context of Indiana public libraries”, LIBRES, Vol. 17 No. 2, pp. 1-19.

Reading Agency (2011), Libraries and Digital: Research into the Use of Digital Media in Libraries to Develop Audiences for Reading, Reading Agency, London. 
Sobel, D.L. (2003), "Internet filters and public libraries: first reports", available at: www.firstamendmentcenter.org/madison/wp-content/uploads/2011/03/Internetfilters. pdf (accessed 15 April 2015).

Society of Chief Librarians (SCL) (2014), "Universal offers", available at: www.goscl.com/ universal-offers/about-universal-offers/ (accessed 10 February 2015).

Spacey, R., Cooke, L., Creaser, C. and Muir, A. (2013), "Regulating internet access and content in UK public libraries: findings from the MAIPLE project”, Journal of Librarianship and Information Science, Vol. 47 No. 1, pp. 71-84.

Spacey, R., Cooke, L., Muir, A. and Creaser, C. (2014), "Regulating use of the Internet in public libraries: a review”, Journal of Documentation, Vol. 70 No. 3, pp. 478-497.

Still, J. and Kassabian, V. (1999), "The mole's dilemma: ethical aspects of public internet access in academic libraries", Internet Reference Services Quarterly, Vol. 4 No. 3, pp. 7-23.

Sturges, P. (2002), Public Internet Access in Libraries and Information Services, Facet Publishing, London.

Telecommunications Act (1984).

Trushina, I. (2004), "Freedom of access: ethical dilemmas for internet librarians", The Electronic Library, Vol. 22 No. 5, pp. 416-421.

United Nations (1989), "Convention on the rights of the child”, available at: www.ohchr.org/en/ professionalinterest/pages/crc.aspx (accessed 10 February 2015).

Willard, N. (2002), "Filtering software: the religious connection”, available at: www.ntia.doc.gov/ legacy/ntiahome/ntiageneral/cipacomments/pre/willard/FSRCreport.htm (accessed 15 April 2015).

Willson, J. and Oulton, T. (2000), "Controlling access to the internet in UK public libraries", OCLC Systems and Services, Vol. 16 No. 4, pp. 194-201.

Young, S. (1997), "Sexually-explicit materials via the internet: ethical concerns for the library profession”, Journal of Academic Librarianship, Vol. 23 No. 1, pp. 49-50.

\section{Further reading}

Chartered Institute of Library and Information Professionals (2014), "Ethics", available at: www. cilip.org.uk/cilip/about/ethics (accessed 10 February 2015).

Jaeger, P.T., Bertot, J.C., McClure, C.R. and Langa, L.A. (2006), “The policy implications of internet connectivity in public libraries", Government Information Quarterly, Vol. 23 No. 1, pp. 123-141.

Protection of Children Act 1999.

United Nations (1948), "The Universal declaration of human rights”, available at: www.un.org/ en/documents/udhr/ (accessed 10 February 2015).

\section{About the authors}

Dr Adrienne Muir is Professor of Information Management in the Aberdeen Business School at Robert Gordon University. Her research interests include information and publishing law, policy and ethics and preservation of intellectual heritage. Prof Muir was Co-Investigator on the MAIPLE (Managing Access to the Internet in Public Libraries) project which was funded by the UK Arts and Humanities Research Council (AHRC). Adrienne Muir is the corresponding author and can be contacted at: a.muir3@rgu.ac.uk

Dr Rachel Spacey a Post Doctoral Research Fellow in the Vice Chancellor's Office at the University of Lincoln. She was the Institutional Researcher on the Postgraduate Experience 
JICES

14,1

Project funded by HEFCE. Dr Spacey was formerly Senior Research Associate, LISU, in the School of Business and Economics at Loughborough University. She was also the Researcher on the Managing Access to the Internet in Public Libraries project.

Dr Louise Cooke is Senior Lecturer in Information and Knowledge Management in the School of Business and Economics at Loughborough University. She was also Principal Investigator on the MAIPLE project which was funded by the UK AHRC. The project, which finished in August 2014, has investigated the measures taken in UK public libraries to manage acceptable use of internet access facilities.

Claire Creaser has been Director of LISU, Loughborough University, since 2007. Her main areas of interest are in the use of statistical evidence for management, with a particular focus on benchmarking; analysis and interpretation of survey data; and scholarly communication. She takes an active role in promoting good statistical practice via several committees, including as Chair of the BSI committee for Library and Publishing Statistics and a member of the Royal Statistical Society Statistics User Forum. Claire Creaser was Co-Investigator on the MAIPLE project which was funded by the UK AHRC.

For instructions on how to order reprints of this article, please visit our website: www.emeraldgrouppublishing.com/licensing/reprints.htm Or contact us for further details: permissions@emeraldinsight.com 